\title{
Application of quality assurance programs in small dairy plants
}

\begin{abstract}
Hazard Analysis and Critical Control Points (HACCP) is one of the most important systems in quality assurance programs, HACCP system is a plant-specific and productspecific quality system. So, application of HACCP system plan in small-scale cheese plant of fresh Domiati cheese was investigated to identify microbiological and chemical hazards and determine the Critical Control Points (CCPs). The results indicated that the raw milk was the most hazardous and very important $\mathrm{CCP}$ as a raw material, because it contained high total bacterial count $(2.5 \times 108 \mathrm{cfu} / \mathrm{ml})$ and high total fungi $\left(8.5 \times 10^{5} \mathrm{cfu} / \mathrm{ml}\right)$ as well as pathogenic bacteria such as Campylobacter and faecal coliform. Also, manufacture processing steps; raw milk receiving, pasteurization and cheese storage steps were the CCPs used to eliminate, prevent or minimize different hazards. The total bacterial count in the final cheese product decreased from $2.1 \times 108$ to $3.1 \times 10^{6} \mathrm{cfu} / \mathrm{g}$ after application of HACCP system. Also, total fungi, total and faecal coliform and Campylobacter were not detected in the final cheese product, which become acceptable according to the Egyptian Standards after HACCP application. On the other hand, pathogenic microorganisms; Pseudomonas aeruginosa, Bacillus cereus, Yersinia enterocolitica, Salmonella spp and Listeria monocytogenes were not detected at all before and after application of HACCP system. All guidelines for the implementation of HACCP system including a flow diagram of processing steps, identifying hazards, controlling at different CCPs through monitoring and corrective actions and verifying the HACCP plan as well as record keeping were also established.
\end{abstract}

Keywords: HACCP, domiati cheese, dairy product, pathogenic bacteria, quality assurance
Volume 7 Issue I - 2017

\author{
Nasr NF, El-Gizawy SA, Zahra MK \\ Department of Microbiology, Cairo University, Egypt
}

Correspondence: NF Nasr, Department of Microbiology, Faculty of Agriculture, Cairo University, Giza, Egypt, Email nasrfawzy93@yahoo.com

Received: February 09, 2017 | Published: August 30, 2017
Abbreviations: HACCP, hazard analysis critical control points; FDA, food and drug administration; CCPs, critical control points; NASA, national aeronautics and space administration; MPN, most probable number; TBA, thiobarbituric acid

\section{Introduction}

Traditional quality assurance programs and facility inspections have proven to be inadequate in controlling many food-borne illnesses. ${ }^{1}$ Also, results of the WHO surveillance program ${ }^{2}$ indicate that the number of causative agents of food-borne diseases continues increase. The best way to achieve disease reduction and food product quality assurance is through implementation of the preventative system of Hazard Analysis Critical Control Points (HACCP) from production to consumption of dairy products. ${ }^{3}$ HACCP is a system that was developed for assuring pathogen free foods for the space program by the Pillsbury Company, the U.S. Army and the National Aeronautics and Space Administration (NASA) in the 1960s. Food and Drug Administration (FDA) has considered developing regulations of HACCP system for the dairy industry. ${ }^{1,4}$

The HACCP system is a systematic approach to the identification and assessment of risk and use preventative actions to control of the microbiological, chemical and physical hazards associated with each segment of the food chain from the production to consumption following the seven basic principles, which are used to develop and implement a HACCP program as follows: Analyze hazards, determine Critical Control Points (CCPs), establish critical limits for CCPs, monitor CCPs, take corrective action, record keeping and verify that the system is working. ${ }^{5}$ The goal of these CCPs is to ensure that food safety hazard can be prevented, controlled, reduced or eliminated. Most of the hazards are brought in by raw materials. ${ }^{6}$ Cheese is the most popular dairy products in the world, produced in a great rang of types and forms throughout the world countries. ${ }^{7}$ Most large cheese manufactory companies have implemented HACCP system to produce safe and good quality product. HACCP is a plant-specific and product-specific quality system. ${ }^{6}$

This work aims to study application and implementation of HACCP system plan as a food safety tool during fresh Domiati cheese production in Dairy Technology Unit, Faculty of Agriculture, Cairo University as a small-scale cheese plant, to identify microbiological and chemical hazards and determine the Critical Control Points (CCPs) in fresh Domiati cheese production line.

\section{Materials and methods}

\section{Samples}

Processing steps of cheese production line were followed by collection samples at each step; also samples were taken from the raw materials such as; raw milk, salt and rennet enzyme as well as the water supply. The samples were collected in sterilized containers and transferred directly to the laboratory and analyzed without delay for microbiology, but preserved in freezer for chemical tests. Different swabs were taken from the equipments, utensils, work surfaces and food handlers during production processes. 


\section{Manufacturing technique of fresh domiati cheese}

Manufacture is illustrated in flow diagram (Figure 1) and could be summarized as follows: Raw milk was received and kept at $4^{\circ} \mathrm{C}$ and standardized. Then milk was pasteurized at $72^{\circ} \mathrm{C}$ for $15 \mathrm{sec}$ and cooled to $40^{\circ} \mathrm{C}$, then salted with $3 \%$ salt $(\mathrm{Nacl})$. Rennet enzyme was added to the milk which kept at $40^{\circ} \mathrm{C}$ for $2 \mathrm{hr}$ for protein coagulation and curd forming. After coagulation, the curd was cut and pressed for $24 \mathrm{hr}$ to remove the whey. Cheese was cut and packaged and stored at $5^{\circ} \mathrm{C}$ for $1-2$ weeks until consumption.

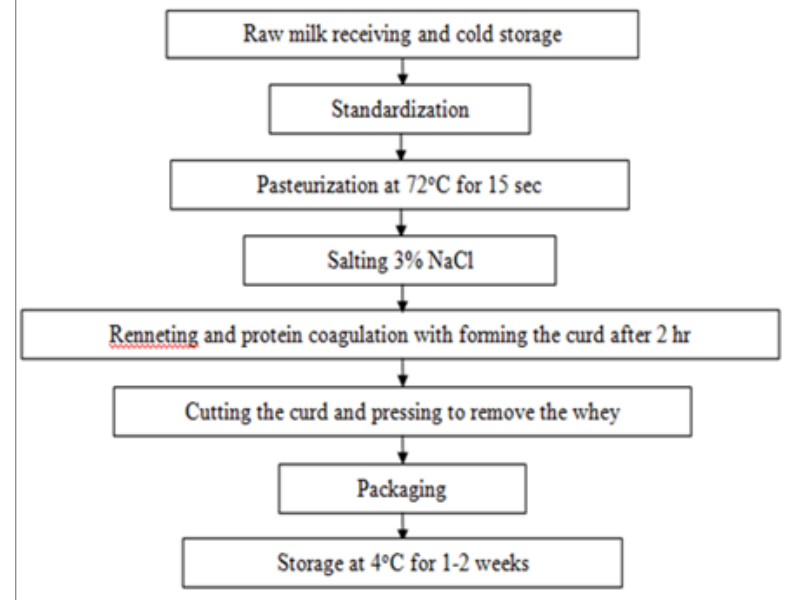

Figure I Flow diagram of fresh Domiati cheese manufacturing steps carried out in Dairy Technology Unit, Faculty of Agriculture, Cairo University.

\section{Microbiological determinations}

Serial dilutions were directly prepared from the liquid samples such as milk, whey, water and rennet enzyme, but with the solid samples such as salt, cheese curd and cheese product, ten grams of the sample were mixed in a blender with $90 \mathrm{ml}$ of saline to obtain the first dilution. Samples were examined for counting of some microbial groups as well as the detection of some pathogenic bacteria.

Counting of microbial groups: Each group was mentioned in relation to its specific medium and the technique of determination.

a. Total viable bacterial count, Trypticase soy agar medium $+0.6 \%$ yeast extract, ${ }^{8}$ pour-plate method (cfu/ml or g) at $30^{\circ} \mathrm{C}$ for $48 \mathrm{hr}$.

b. Total spore-forming bacteria, Trypticase soy agar medium $+0.6 \%$ yeast extract, ${ }^{8}$ pour-plate method (cfu/ml or g) at $30^{\circ} \mathrm{C}$ for $48 \mathrm{hr}$ with pasteurization the dilutions at $80^{\circ} \mathrm{C}$ for $15 \mathrm{~min}$.

c. Total fungi, Rose Bengal chloramphenicol agar medium, ${ }^{8}$ pourplate method (cfu/ml or g) at $25^{\circ} \mathrm{C}$ for $5-7$ days.

d. Total coliform, MacConkey broth purple medium, ${ }^{9}$ most probable Number (MPN) technique at $37^{\circ} \mathrm{C}$ for $24 \mathrm{hr}$.

e. Faecal coliform, MacConkey broth purple medium, ${ }^{9}$ most probable Number (MPN) technique at $44.5^{\circ} \mathrm{C}$ for $24 \mathrm{hr}$.

Counting of some pathogenic bacteria: Some of pathogenic bacteria can be counted directly using specific selective culture media.

\section{i. Pseudomonas aeruginosa}

Asparagine enrichment broth medium ${ }^{10}$ could be used for counting of Pseudomonas aeruginosa by using Most Probable Number (MPN) technique at $35^{\circ} \mathrm{C}$ for $48 \mathrm{hr}$. The positive tubes, where presence of a green blue fluorescent pigment.

\section{ii. Bacillus cereus}

It could be counted using Bacillus cereus selective agar medium ${ }^{11}$ and pour plate technique (cfu/ml or g) at $37^{\circ} \mathrm{C}$ for $48 \mathrm{hr}$. B. cereus colonies are characterized as $5 \mathrm{~mm}$ in diameter, turquoise blue in color, surrounded by distinct opaque zone of egg yolk precipitation with the same color.

\section{iii. Staphylococcus aureus}

Staphylococcus aureus cells were counted by pour plate technique using Vogel - Johnson agar medium. ${ }^{12}$ Plates were incubated at $37^{\circ} \mathrm{C}$ for $48 \mathrm{hr}$ with the examination after $24 \mathrm{hr}$. typical colonies appeared as black colonies surrounded by a yellow zone.

\section{iv. Yersinia spp}

Cefsulodin Irgasan Novobiocin agar ${ }^{13}$ was used for counting of Yersinia spp. using pour plate technique with spreading inoculation (cfu/ml or g) at $22-32^{\circ} \mathrm{C}$ for $24-48 \mathrm{hr}$. Colonies of Yersinia appeared dark purple (bulls-eye) with translucent edge sometimes surrounded by precipitated bile zone.

Detection of some pathogenic bacteria: Some of pathogenic bacteria can be detected and isolated using selective procedures.

\section{a. Salmonella spp}

Bottle of selenite cystine broth medium ${ }^{14}$ was inoculated with 10 $25 \mathrm{ml}$ or $\mathrm{g}$ of the sample and incubated at $37^{\circ} \mathrm{C}$ for $24 \mathrm{hr}$. Full loop from this bottle was streaked onto plates of XLD agar medium, ${ }^{15}$ then plates were incubated at $37^{\circ} \mathrm{C}$ for $24-48 \mathrm{hr}$. Typical colonies of Salmonella spp. were red colonies with black centers.

\section{b. Listeria monocytogenes}

Detection and isolation procedures of Listeria spp. were followed according to the method of IDF. ${ }^{16}$ It is a provisional International Dairy Federation recommended method for milk and milk products and the following steps were applied: Twenty -fiveml or $g$ of the product were added to $225 \mathrm{ml}$ of Listeria enrichment broth medium, ${ }^{17}$ then mixed and carefully homogenized and incubated at $30^{\circ} \mathrm{C}$ for 48 hours. A loopfull of enriched culture was streaked onto plates of Agar listeria ottavian \& agosti (ALOA) medium ${ }^{18}$ and incubated at $37^{\circ} \mathrm{C}$ for $48 \mathrm{hr}$. Colonies of Listeria monocytogenes appeared light blue surrounded by an opaque halo, while, other Listeria spp. appeared light blue without opaque halo.

\section{c. Campylobacter spp}

Detection method of Campylobacter spp. was followed according to Oosterom et al..$^{19}$ Twoml or $\mathrm{g}$ of the sample were put in $20 \mathrm{ml}$ of supplemented Thioglycollate broth medium and incubated at $37^{\circ} \mathrm{C}$ for $24 \mathrm{hr}$ under microaerophilic conditions $(6 \% \mathrm{O} 2$ and $10 \% \mathrm{CO} 2)$. One loopfull of the broth was streaked on supplemented Skirrow's agar. The plates were incubated at $43^{\circ} \mathrm{C}$ for $48 \mathrm{hr}$ under microaerophilic conditions. Campylobacter spp. colonies were small grey flat colonies with irregular edge.

\section{Chemical analysis}

\section{i. Aflatoxins}

Aflatoxin M1 was determined by Thin-Layer Chromatographic method according to AOAC Official Methods of Analysis. ${ }^{20}$

\section{ii. Thiobarbituric acid (TBA)}

TBA test was used to determine the amount of TBA reactive 
substances as indicator for oxidized fat in the milk and cheese samples. $^{21}$

\section{iii. Heavy metals}

Heavy metals ( $\mathrm{Cd}, \mathrm{Se}, \mathrm{Pb}$ and $\mathrm{Co}$ ) were determined using Atomic Absorption method according to AOAC Official Methods of Analysis. $^{22}$

\section{Statistical analysis}

All samples have been taken in triplicate. The average $(\mathrm{X})$ and standard deviation (SD) were calculated.

\section{Developing the HACCP Plan}

Hazard analysis and determination of critical control points of the raw materials (Figure 2) and processing steps (Figure 3) were carried out according to Mortimore \& Wallace. ${ }^{23}$

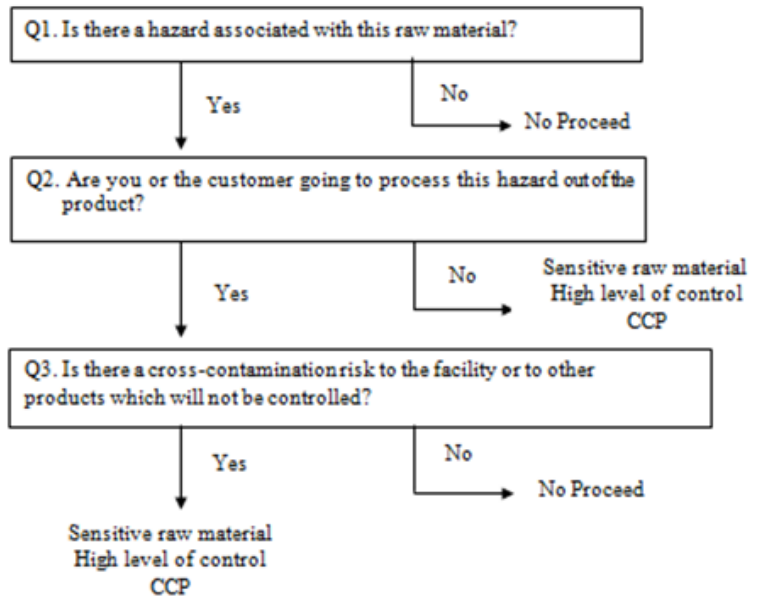

Figure 2 Diagram of decision tree to identify CCPs of the raw materials. ${ }^{23}$

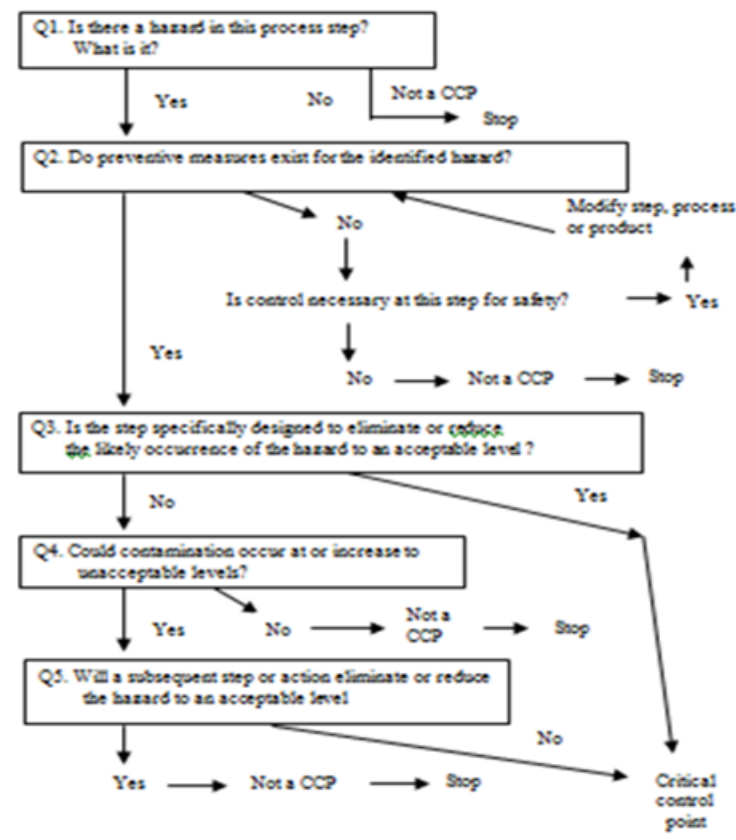

Figure 3 Diagram of decision tree to identify CCPs of processing steps. ${ }^{23}$

\section{Results and discussion}

Application of Hazard Analysis and Critical Control Points (HACCP) program in fresh Domiati cheese production line:

\section{Conduct hazard analysis}

The hazard analysis for soft cheese manufacture is to identify different hazards in the various raw materials and steps of processing and consideration of control measures for the hazards. ${ }^{24}$

Biological hazards: Raw materials are considered the main source of biological hazards and the raw milk is the most important source of pathogenic bacteria. Table 1 shows the average of microbiological analysis of raw materials, where the raw milk contained high load of total bacterial count $2.5 \times 10^{8} \mathrm{cfu} / \mathrm{ml}$ and contained $1.2 \times 10^{3}$ and $8.5 \times 10^{5} \mathrm{cfu} / \mathrm{ml}$ spore-forming bacteria and total fungi. Also, total and faecal coliforms were found $4.5 \times 10^{3}$ and $2.5 \times 10^{3} / \mathrm{ml}$, this result indicate that the production of milk lack hygienic practices. In the same direction, Aboul-Khier et al., ${ }^{25}$ reported that total coliform occurred in all of 40 raw milk samples ranged from $6.0 \times 10^{5}$ to $1.2 \times 10^{6} / \mathrm{ml}$, but faecal coliform detected only in $85 \%$ of samples ranged from $2.4 \times 10^{4}$ to $3.4 \times 10^{4} / \mathrm{ml}$ in Sohage city, Egypt. On the other hand, Campylobacter was detected in raw milk, but Pseudomonas aeruginosa, Bacillus cereus, Staphylococcus aureus, Yersinia enterocolitica, Salmonella spp and Listeria monocytogenes were not detected in raw milk samples which were acceptable according to Egyptian Standards. ${ }^{26}$ On contrary, Listeria monocytogenes was recovered from $2 \%$ and $4 \%$ of cow and goat milk samples, respectively, from Mansoura city, Egypt. ${ }^{27}$ On the other hand, although rennet enzyme contained $8.3 \times 10^{6}, 1.0 \times 10^{2}$ and $1.2 \times 10^{6} \mathrm{cfu} / \mathrm{ml}$ total bacterial counts, spore-forming bacteria and total fungi, respectively, and $2.5 \times 10^{2}$ total coliform count $/ \mathrm{ml}$, but it was not in the same importance of raw milk as hazards source, because pathogenic bacteria were not detected in rennet enzyme, which also added in small amount for coagulation. On contrary, salt and water contained low counts of microorganisms.

Equipments, utensils, work surfaces and food handlers are very important sources for microbial contamination of cheese product during processing steps, so swabs from containers, utensils, food handlers, tables, walls, packaging material and refrigerator were microbiologically investigated. The results (Table 2) indicated that, hazardous pathogenic bacteria were not detected in all swabs except Campylobacter that was detected from utensils, tables, walls and food handlers which contained total bacterial counts around $10^{4} \mathrm{cfu} /$ $\mathrm{cm}^{2}$, while the packaging material has the lowest total bacterial count $2.2 \times 10 \mathrm{cfu} / \mathrm{cm}^{2}$. Total fungi were found in all swabs in counts from $1.1 \times 10$ to $4.8 \times 10^{3} \mathrm{cfu} / \mathrm{cm}^{2}$. Spore-forming bacteria not detected in packaging material and food handlers swabs, but found in other swabs between $2.1 \times 10$ to $5.7 \times 10^{3} \mathrm{cfu} / \mathrm{cm}^{2}$. Also, total coliform was not found in walls and refrigerator swabs and found in other swabs in few numbers, but faecal coliform not detected in all swabs.

Manufacture processing steps affect the microbial load of the cheese product; (Table 3 ) shows the microbiological analysis during processing steps of cheese before HACCP system application. After receiving of raw milk, the microbial load was not affected by standardization of milk composition step, but pasteurization was the most effective step to reduce the microbial counts and destroy pathogenic bacteria, where total bacterial count and sporeforming bacteria decreased from $1.2 \times 10^{8}$ and $1.1 \times 10^{3}$ to $1.5 \times 10^{4}$ and $1.3 \times 10^{2} \mathrm{cfu} / \mathrm{ml}$, also fungi, coliform and Campylobacter were 
completely destroyed, but Staphylococcus aureus appeared after pasteurization with $7.2 \times 10^{2} \mathrm{cfu} / \mathrm{ml}$. During salting, renneting and coagulation, cutting the curd and removing the whey and packaging steps, the milk and cheese curd were contaminated by fungi, coliform,
Staphylococcus aureus and Campylobacter from raw materials (salt and rennet enzyme), equipments, utensils, work surfaces and food handlers. The growth of these microorganisms during these steps caused an increase in microbial counts.

Table I Microbiological examination of raw materials used in cheese manufacture $\left(X \pm S_{D}\right)$.

ND, not detected; +ve, positive; -ve, negative

\begin{tabular}{|c|c|c|c|c|}
\hline \multirow{2}{*}{ Microbiological tests } & \multicolumn{4}{|l|}{ Raw materials } \\
\hline & Raw milk & Salt & Rennet enzyme & Water \\
\hline Total Bacterial Count (cfu/ml or g) & $2.5 \times 10^{8} \pm 2.1 \times 10^{8}$ & $8.7 \times 10^{3} \pm 1.5 \times 10^{3}$ & $8.3 x^{6} \pm 1.7 \times 10^{6}$ & $5.2 \times 10 \pm 4.1 \times 10$ \\
\hline Spore-Forming Bacteria (cfu/ml or g) ))gg) & $1.2 \times 10^{3} \pm 1.1 \times 10^{3}$ & $4.0 \times 10^{3} \pm 3.5 \times 10^{3}$ & $1.0 \times 10^{2} \pm 0.5 \times 10^{2}$ & $1.0 \times 10 \pm 0.7 \times 10$ \\
\hline Total Fungi (cfu/ml or g) & $8.5 \times 10^{5} \pm 1.5 \times 10^{5}$ & ND & $1.2 \times 10^{6} \pm 0.9 \times 10^{6}$ & $1.0 \times 10 \pm 0.5 \times 10$ \\
\hline Total Coliforms / $\mathrm{ml}$ or $\mathrm{g}$ & $4.5 \times 10^{3} \pm 3.2 \times 10^{3}$ & ND & $2.5 \times 10^{2} \pm 1.7 \times 10^{2}$ & ND \\
\hline Faecal Coliforms /ml or g & $2.5 \times 10^{3} \pm 1.1 \times 10^{3}$ & ND & ND & ND \\
\hline Pseudomonas aeruginosa $/ \mathrm{ml}$ or $\mathrm{g}$ & ND & ND & ND & ND \\
\hline Bacillus cereus (cfu/ml or g) & ND & ND & ND & ND \\
\hline Staphylococcus aureus (cfu/ml or g) & ND & ND & ND & ND \\
\hline Yersinia enterocolitica (cfu/ml or g) & ND & ND & ND & ND \\
\hline Salmonella spp & -ve & -ve & -ve & -ve \\
\hline Listeria monocytogenes & -ve & -ve & -ve & -ve \\
\hline Campylobacter spp & $+\mathrm{ve}$ & -ve & -ve & -ve \\
\hline
\end{tabular}

Table 2 Microbiological examination of the swab samples taken from different locations in production line ND, not detected; +ve, positive; -ve, negative

\begin{tabular}{|c|c|c|c|c|c|c|c|}
\hline \multirow{2}{*}{ Microbiological tests } & \multicolumn{7}{|l|}{ Swabs } \\
\hline & Containers & Utensils & $\begin{array}{l}\text { Food } \\
\text { handlers }\end{array}$ & Tables & Walls & $\begin{array}{l}\text { Packaging } \\
\text { material }\end{array}$ & Refrigerator \\
\hline Total Bacterial Count $\left(\mathrm{cfu} / \mathrm{cm}^{2}\right)$ & $2.2 \times 10^{2}$ & $3.4 \times 10^{4}$ & $1.1 \times 10^{4}$ & $2.6 \times 10^{4}$ & $7.2 \times 10^{4}$ & $2.2 \times 10$ & $3.1 \times 10^{2}$ \\
\hline Spore-Forming Bacteria $\left(\mathrm{cfu} / \mathrm{cm}^{2}\right)$ & $1.3 \times 10$ & $2.4 \times 10^{2}$ & ND & $5.7 \times 10^{3}$ & $2.5 \times 10^{3}$ & ND & $2.1 \times 10$ \\
\hline Total Fungi (cfu/ $\left.\mathrm{cm}^{2}\right)$ & $5.1 \times 10$ & $2.1 \times 10$ & $1.1 \times 10^{2}$ & $4.8 \times 10^{3}$ & $2.3 \times 10^{2}$ & $1.1 \times 10$ & $2.1 \times 10^{2}$ \\
\hline Total Coliforms $/ \mathrm{cm}^{2}$ & $4.0 \times 1$ & $1.1 \times 10$ & $2.5 \times 10$ & $3.0 \times 10$ & ND & $0.6 \times 1$ & ND \\
\hline Faecal coliform $/ \mathrm{cm}^{2}$ & ND & ND & ND & ND & ND & ND & ND \\
\hline Pseudomonas aeruginosa $/ \mathrm{cm}^{2}$ & ND & ND & ND & ND & ND & ND & ND \\
\hline Bacillus cereus (cfu/cm²) & ND & ND & ND & ND & ND & ND & ND \\
\hline Staphylococcus aureus $\left(\mathrm{cfu} / \mathrm{cm}^{2}\right)$ & ND & ND & ND & ND & ND & ND & ND \\
\hline Yersinia enterocolitica $/ \mathrm{cm}^{2}$ & ND & ND & ND & ND & ND & ND & ND \\
\hline Salmonella spp & -ve & -ve & -ve & -ve & -ve & -ve & -ve \\
\hline Listeria monocytogenes & -ve & -ve & -ve & -ve & -ve & -ve & -ve \\
\hline Campylobacter spp & -ve & $+\mathrm{ve}$ & $+\mathrm{ve}$ & $+\mathrm{ve}$ & $+\mathrm{ve}$ & -ve & -ve \\
\hline
\end{tabular}


Finally, after storage step, Domiati cheese (Table 3) contained $2.1 \times 10^{8}, 2.3 \times 10^{2}$ and $6.7 \times 10^{5} \mathrm{cfu} / \mathrm{g}$ total bacterial count, sporeforming bacteria and total fungi, respectively, and faecal coliform count $1.4 \times 10^{4} / \mathrm{g}$, this result is in agreement with those of Said and Fahmy ${ }^{28}$ who isolated cells of Escherichia coli from 32 samples out of 50 samples of Domiati cheese collected from Assiut city, Egypt. The result indicated that, the final cheese product was unacceptable according to Egyptian Standards. ${ }^{29}$ Campylobacter was isolated from the final cheese product, but Pseudomonas aeruginosa, Yersinia enterocolitica, Salmonella spp, Listeria monocytogenes, Bacillus cereus and Staphylococcus aureus were not detected. On contrary, Said and Fahmy ${ }^{28}$ detected Bacillus cereus and Staphylococcus aureus in 48 and $72 \%$ of 50 Domiati cheese samples taken from Assiut city, Egypt. From the previous, it is clear that biological hazards were fungi, coliform, Staphylococcus aureus and Campylobacter which come from raw milk and rennet enzyme as raw materials and food handlers, utensils and work surfaces during manufacture.

Table 4 Chemical hazards of raw materials used in cheese manufacture, cheese product and whey

ND, not determined

\begin{tabular}{|c|c|c|c|c|c|c|}
\hline \multirow{2}{*}{ Samples } & \multirow{2}{*}{ Thiobarbituric acid (TBA ) mg/kg } & \multirow{2}{*}{ Aflatoxin $M_{1} \mathrm{mg} / \mathrm{kg}$} & \multicolumn{4}{|c|}{ Heavy metals mg/kg } \\
\hline & & & Cd & Se & $\mathbf{P b}$ & Co \\
\hline Raw Milk & II. .07 & 0 & Nil & Nil & Nil & Nil \\
\hline Salt & ND & ND & Nil & Nil & Nil & Nil \\
\hline Rennet Enzyme & 4.029 & 0 & ND & ND & ND & ND \\
\hline Cheese Curd & 0.027 & 0 & Nil & Nil & Nil & Nil \\
\hline Whey & 0.096 & 0 & Nil & Nil & Nil & Nil \\
\hline
\end{tabular}

Chemical hazards: Food products can be polluted by chemical hazards from raw materials, during manufacture or as a result of chemical spoilage. As shown in Table 4 raw materials; raw milk and salt and cheese curd were free of $\mathrm{Cd}, \mathrm{Se}, \mathrm{Pb}$ and Co heavy metals, also raw milk, rennet enzyme and cheese curd were free of Aflatoxin M1, but raw milk and rennet enzyme contained 11.070 and $4.029 \mathrm{mg} / \mathrm{kg}$ Thiobarbituric acid (TBA) as a result of fat oxidation.

\section{Determine critical control points (CCPs)}

CCPs are points or areas in a process that are required to control the identified hazards and lack of control is likely to result in unacceptable health hazards. ${ }^{30}$ CCPs in raw materials and processing line steps (Figure 4) of fresh Domiati cheese were determined according to CCP decision tree (Figure 2) (Figure 3) of Mortimore \& Wallace. ${ }^{23}$ For the raw materials, it is clear that the raw milk was very important CCP; on the other hand, (Figure $4 \&$ Table 5) show that, raw milk receiving at $4-6^{\circ} \mathrm{C}$, pasteurization at $72^{\circ} \mathrm{C}$ for $15 \mathrm{sec}$ and storage of cheese product at $4-6^{\circ} \mathrm{C}$ steps were the main CCPs in the processing line of fresh Domiati cheese.

\section{Establish critical limits}

The critical limits provide the base line for measuring the effectiveness of food safety procedures. These limits are needed to minimize or eliminate significant food safety hazards. Table 5 Summarizes the critical limits for each processing steps, the critical limits for raw milk receiving step were raw milk standards and receiving milk at temperature less than $6^{\circ} \mathrm{C}$; for pasteurization step, the heat temperature must not less than $72^{\circ} \mathrm{C}$ for $15 \mathrm{sec}$ and for storage of cheese product step, the storage temperature must not more than $6^{\circ} \mathrm{C}$.

\section{Establish monitoring procedures}

The temperature should be monitored by a calibrated thermometer at every step with monitoring the time with some steps such as pasteurization. A number of non continuous monitoring procedures could be used such as rapid platform tests with raw milk receiving step and microbiological and chemical tests for raw materials and packaging material (Table 5).

\section{Establish corrective actions}

Corrective actions should be taken when monitoring system indicate that, any of the critical limits was out of control. Corrective actions with every step were summarized in Table 5 such as rejection of contaminated raw materials, ${ }^{31}$ correction and resetting of pasteurizer temperature and time, maintenance or repairing of separator and pasteurizer and discarding the product if contamination was evident.

\section{Record keeping}

Documentation is needed to record measurements that show standards are being monitored. Effective HACCP record-keeping plan contains; listing of the HACCP team and responsibilities, description of the food and its intend use, list all regulations that must be met, temperature monitoring logs, flow chart from receiving to consumption and corrective actions. Accurate record keeping is essential part of successful HACCP plan.

\section{Verification of HACCP system working}

Verification of HACCP system includes routine calibration of CCPs monitoring system, testing of finished product and random collection of raw materials and end product, and then testing them chemically and microbiologically. The overall HACCP process must be verified periodically to be sure that, the HACCP system is effective and work well. describe the microbiological analysis during processing steps of cheese after HACCP application, the result indicate that, Pseudomonas aeruginosa, Bacillus cereus, Yersinia enterocolitica, Salmonella spp and Listeria monocytogenes were not detected at 
all, while, fungi, total and faecal coliform and Campylobacter were not detected after pasteurization step and in the final cheese product which become acceptable according to Egyptian Standards ${ }^{30}$ after HACCP application. On the other hand, Staphylococcus aureus appeared after pasteurization step with $1.1 \times 10^{2} \mathrm{cfu} / \mathrm{ml}$, but its count decreased during the next steps to be not detected in the final cheese product. Total bacterial count and spore-forming bacteria in the final cheese product were $3.1 \times 10^{6}$ and $7.2 \times 10 \mathrm{cfu} / \mathrm{g}$, in comparison with $2.1 \times 10^{8}$ and $2.3 \times 10^{2} \mathrm{cfu} / \mathrm{g}$ in the final cheese product before HACCP application (Table $3 \&$ Table 6).

\section{Raw Materials}

\section{Processing steps}

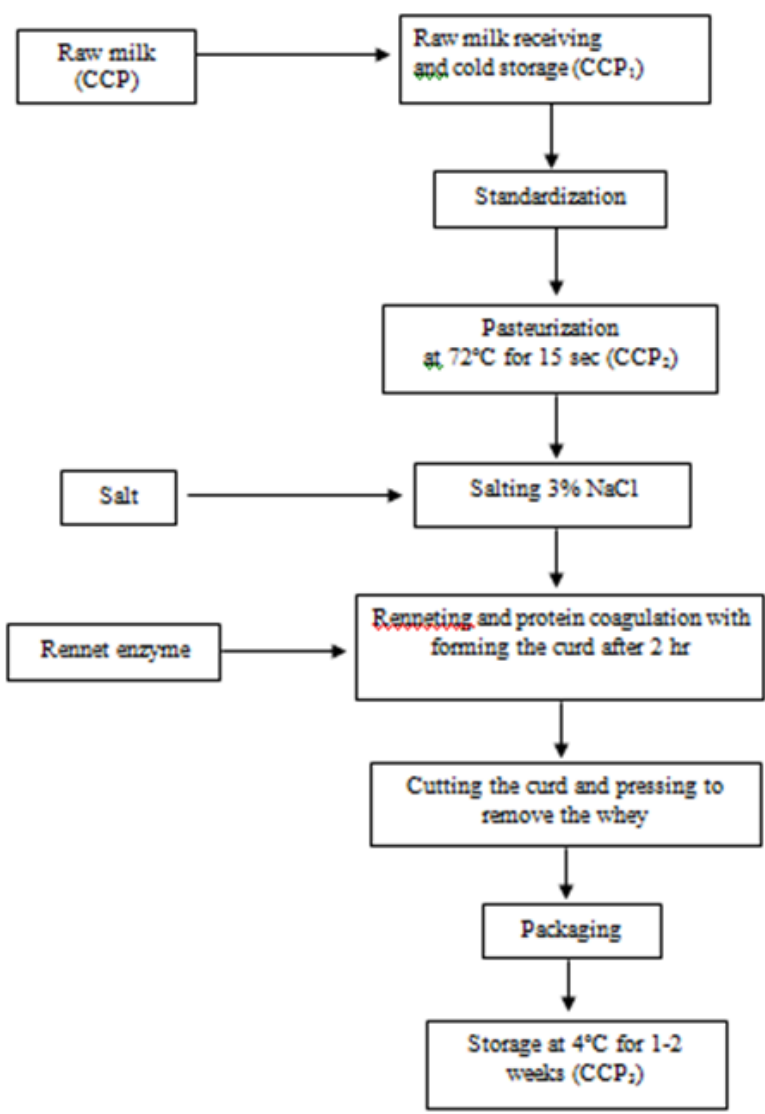

Figure 4 Flow diagrams of the fresh Domiati cheese manufacturing steps and CCPs for controlling hazards.

\section{Conclusion}

From the obtained results, it could be concluded that:

i. The development and implementation of HACCP program is reliable to secure the safety of food.

ii. HACCP was developed as a "zero defects" program for food safety.

iii. HACCP is a plant-specific and product-specific quality system.

iv. HACCP system can be applied in small-scale cheese plant of fresh Domiati cheese.

v. Quality Assurance programs can be applied in small-scale dairy plants.

\section{Acknowledgements}

None.

\section{Conflict of interest}

The author declares no conflict of interest.

\section{References}

1. Riswadkar AV. An introduction to HACCP, the Hazard Analysis and Critical Control Point system for food processors. Professional Safety. 2000;45(6):33-36.

2. WHO. WHO surveillance programme for control of food-borne infections and intoxications in Europe, Fifth Report, Inst Vet Med Report von Ostertag Institute, Berlin, Germany; 1992.

3. Roberts MR, Pearson AM, Dutson TR. The HACCP program and the consumer. In HACCP in meat, poultry and fish processing. Food Science \& Nutrition. 1995;10:301-317.

4. Bardic A. HACCP ready. Dairy Field. 2001;189(2):6.

5. Corlett DA. HACCP user's manual. Maryland: Aspen publishers; 1998.

6. Zhao M. The design of HACCP plan for a small-scale cheese plant USA: The Graduate School University of Wisconsin- Stout; 2003.

7. Fox PF. Cheese:an overview in Cheese: Chemistry, Physics and Microbiology. US: Chapman Hall, Springer; 1993:1-36.

8. Marth EH. Standard methods for the examination of dairy products. 14th ed. USA: Food and agriculture organization of united nation, American Public Health Assoc., Inc; 1978.

9. International standards for drinking water. 2nd ed. Geneva: World Health Organization; 1963.

10. Arnold E Greenberg, R Rhodes Trussell, Lenore S Clesceri. Standard methods for the examination of water and waste water. 16th ed. USA: American Public Health Assoc., Inc; 1985:978-980.

11. Mossel DAA, Koopman MJ, Jongerius E. Enumeration of Bacillus cereus in foods. Appl Microbiol. 1967;15(3):650-653.

12. Vogel RA, Johnson M. A modification of the tellurite glycine medium for the use in the identification of Staphylococcus aureus. Public Health Laboratory. 1960;18(6):131-133.

13. Schiemann DA. Synthesis of a selective agar medium for Yersinia enterocolitica. Can J Microb. 1979;25(11):1298-1304.

14. Walter WG. Standard methods for the examination of dairy products. 12th ed. USA: American Public Health Assoc., Inc; 1967.

15. Taylor WJ. Isolation of Shigella.1. Xylose lysine agar; new media for isolation of enteric pathogens. Am J Clin Pathol. 1965;44(4):471-475.

16. IDF. Provisional International Dairy Federation recommended method for milk and milk products, detection of Listeria monocytogenes. Int Dairy Feder Brussels Europe; 1988.

17. Lovett J, Francis DD, Hunt JM. Listeria monocytogenes in raw milk: detection, incidence and pathogenicity. Journal of food protection. 1987;50:188-192.

18. Ottavian F, Ottavian M, Agosti M. Differential agar medium for Listeria monocytogenes. Food and agriculture organization of united nation; 1997. p. 16-18.

19. Oosterom J, Notermans S, Karman H, et al. Origin and prevalence of Campylobacter jejuni in poultry processing. Journal of food protection. 1983;46(4):339-344.

20. AOAC. Official methods of analysis of AOAC international. 17th ed. USA: Association of Official Agricultural Chemists; 2000. 
21. Tarladgis BG, Watts BM, Youmnathan MT, et al. A distillation method for quantitative determination malonaldehyde in rancid foods. Journal of American Oil Chemist Society. 1960;37:44-48.

22. AOAC. Method of analysis. 16th ed. USA: Association of Official Agricultural Chemists; 1995.

23. Mortimore S, Wallace C. HACCP. New York, USA; 1997.

24. Mauropulos AA, Arantoyannis IS. Implementation of hazard analysis critical control points to feta and manouri cheese production lines. Food Control. 1999;10:213.

25. Aboul-Khier FA, El-Bassiony T, Gad El-Rab H. Incidence of coliform organisms in raw milk in Sohag city. Assiut Vet Med J. 1986;15(30):129133.

26. Milk and milk products: Raw milk. Egyptian Organization for Standardization and Quality (EOS), ES; 2005:154-1.
27. Abdel-Khalek A, El-Gamal A, Shehab MM, et al. Occurrence of Listeria species in raw milk in Mansoura. Egypt; 1998. p. 57-64.

28. Said MR, Fahmy MA. A survey of incidence of Staphylococcus aureus, Escherichia coli and Bacillus cereus in some types of Egyptian cheese in Assiut city. Assiut Journal of Agricultural Sciences. 1991;22(2):239246.

29. Soft cheese: Domiati cheese. Egyptian Organization for Standardization and Quality (EOS), ES; 2005:1008-1003.

30. Food and Drug Administration Department of Health and Human Services. Public Health Services, VS Department of Commerce Springfield; 1995.

31. Anon. Recommended international code of practice. General principals of food hygiene. 1997. 